\title{
Waste Paper Pulp Ash as Partial Replacement of cement in Cement Mortar
}

\author{
Melaku Zewdie ${ }^{1}$, Getasew Zewdie ${ }^{2}$, and P.M. Shanmugavadivu ${ }^{1}$ \\ ${ }^{1}$ Addis Ababa Science and Technology University \\ ${ }^{2}$ Dire Dawa University
}

September 12, 2020

\begin{abstract}
The application of cement in various fields of construction makes it a very important engineering material. However, it is very expensive and releases carbon dioxide gas into the atmosphere. Therefore, it is crucial to find cheap and environmentally friendly alternatives to cement. Waste paper pulp ash (WPPA) was found to be one of the most mature cement substitute materials. In this work, the physical and mechanical properties of cement mortar with WPPA as partial replacement of cement were experimentally studied to ensure that the resulting mixes has appropriate mechanical properties. Cement mixes containing various percentage replacements of WPPA $(5 \%, 10 \%, 15 \%$ and $20 \%)$ were prepared, and basic properties such as compressive strength, flexural strength, shear bond strength, efflorescence and water absorption were determined and compared with the control mix $(0 \%)$. The basic mechanical properties of cement mortar containing WPPA are enhanced until the percentage of WPPA reaches $10 \%$. However, a further percentage of WPPA substitution causes the mechanical strength of the mortar to decrease. It is found that the optimal level of WPPA as a cement substitute is $5 \%$. Although the physical properties of WPPA blended paste are improved with the increase of WPPA percentage. Our research provides a typical example of how the use of cement mortar containing WPPA can aid to the development of building materials. In addition to having better mechanical strength, cement-WPPA mixed mortar is a cost effective and environmentally friendly material.
\end{abstract}

\section{Hosted file}

Manuscript_ENGR_Template.docx available at https://authorea.com/users/358646/articles/480732waste-paper-pulp-ash-as-partial-replacement-of-cement-in-cement-mortar

\section{Hosted file}

Tables.docx available at https://authorea.com/users/358646/articles/480732-waste-paper-pulpash-as-partial-replacement-of-cement-in-cement-mortar

\section{Hosted file}

Figures.docx available at https://authorea.com/users/358646/articles/480732-waste-paperpulp-ash-as-partial-replacement-of-cement-in-cement-mortar 